\title{
Hydro Geophysical Investigation of Shebe Watershed, Jimma, South Western Ethiopia
}

\author{
Geremew Lamessa \\ Department of Earth and Environmental Science, College of Natural and Computational Sciences, \\ Wollega University, Nekemte, Ethiopia
}

\begin{tabular}{|c|c|}
\hline Abstract & Article Information \\
\hline $\begin{array}{l}\text { The need to prospect for additional ground water sources in Shebe watershed, Jimma, } \\
\text { Shebe town water supply became inevitable because of the fact that the existed water } \\
\text { supply and the quality of the water with current population and the population for the next } \\
20 \text { years is not enough and it must also be clean. The paper assesses Geological, } \\
\text { Hydrogeophysical and groundwater potential site of Shebe watershed. Desk study, field } \\
\text { study and geophysical survey were carried out with the objective of defining the most } \\
\text { favorable location for borehole in shebe watershed. Survey specification and instruments } \\
\text { used in this study work was latest instrument SAS } 4000 \text { resistivity meter with electrode } \\
\text { spacing of AB/2=>750m and GPS. Data Analysis and interpretation has been done } \\
\text { through different software such as Arc GIS, surfer, and GWW, IPI2win, \& Global mapper. } \\
\text { Thus implementation of sustainable potable water supply through source identification; } \\
\text { how to supply safe/ potable water for the town; identification of recharge-discharge areas; } \\
\text { depth to the water bearing zone; characterizing the aquifer using resistivity distribution } \\
\text { were determined. The hydrogeological study revealed that the area consists of recent } \\
\text { sediment deposits and volcanic rocks. Volcanic rocks are weathered and fractured which } \\
\text { is suitable for groundwater abstraction through deep well drilling and whereas recent } \\
\text { sediment deposits may be suitable for shallow groundwater abstraction. From both } \\
\text { hydrogeophysical investigation VES1 andVES2 results, it was safely concluded that the } \\
\text { target depth for well at Bake Qobo site1 of Shebe watershed should not be less than } \\
140 \text { m \& from the result of VES2 at the Bake Qobo site2, because the fifth layer is } \\
\text { confined between the two aquifer layers, the optimum depth for the water bearing zone } \\
\text { must not be less than } 170 m \text {. }\end{array}$ & $\begin{array}{l}\text { Article History: } \\
\text { Received : 23-03-2012 } \\
\text { Revised : 12-08-2012 } \\
\text { Accepted : 20-08-2012 } \\
\text { Keywords: } \\
\text { Aquifer } \\
\text { Geophysical Survey } \\
\text { Fracture } \\
\text { Sediment Deposit } \\
\text { Volcanic Rocks } \\
\text { *Corresponding Author: } \\
\text { Geremew Lamessa } \\
\text { E-mail: } \\
\text { olbirat2010@gmail.com }\end{array}$ \\
\hline
\end{tabular}

\section{INTRODUCTION}

Water is one of the most important commodities which man had exploited than any other resources for sustenance of his life. The need for water is strongly ascending. It is not only important for domestic purpose but also for the development activities in both agricultural and industrial sectors. Any developmental activity is related, either directly or indirectly, with water utilization.

The need to prospect for additional ground water sources in Shebe watershed, Jimma, Shebe town water supply became inevitable because of the fact that the existed water supply and the quality of the water with current population and the population for the next 20 years is not enough and it must also be clean. Water source for the town is from recently drilled deep well to a depth of $125 \mathrm{~m}$; safe discharge about $7.5 \mathrm{~L} / \mathrm{s}$ at GPs location of $(36 p, 225826 m E, U T M, 829979 m N)$ has good discharge but has quality problem and Finland Mission's shallow well with $66 \mathrm{~m}$ depth found at GPs location of $(36 \mathrm{p}, 225223 \mathrm{mE}, \mathrm{UTM}, 829810 \mathrm{mN})$ low discharge and hence the need to prospect for additional ground water sources in the town is necessary through hydrogeophysical investigation in the watershed. 


\section{Geremew Lamessa}

\section{Description of the Study Area}

The Shebe watershed in which the shebe town located is Shebe Sonbo district (Jimma zone) at about $110 \mathrm{~km}$ North of Jimma town, which is the capital of the Zone, in Oromia National Regional State and Jimma town is located at $350 \mathrm{~km}$ from Addis Ababa and $270 \mathrm{~km}$ from Nekemte to southwest.
STAR Journal, July-Sep 2012, 1(3): 45-58

The Shebe water source identification and investigation, which is the subject of this study, is located in between the UTM coordinates $215500 \mathrm{~m}$ to $239800 \mathrm{~m}$ easting and $825900 \mathrm{~m}$ to $839800 \mathrm{~m}$ northing of zone 37 (Figure 1\&2). Access to the area is via the town of Jimma to southwest $50 \mathrm{~km}$ on gravely all weather roads and asphalt road is under construction.

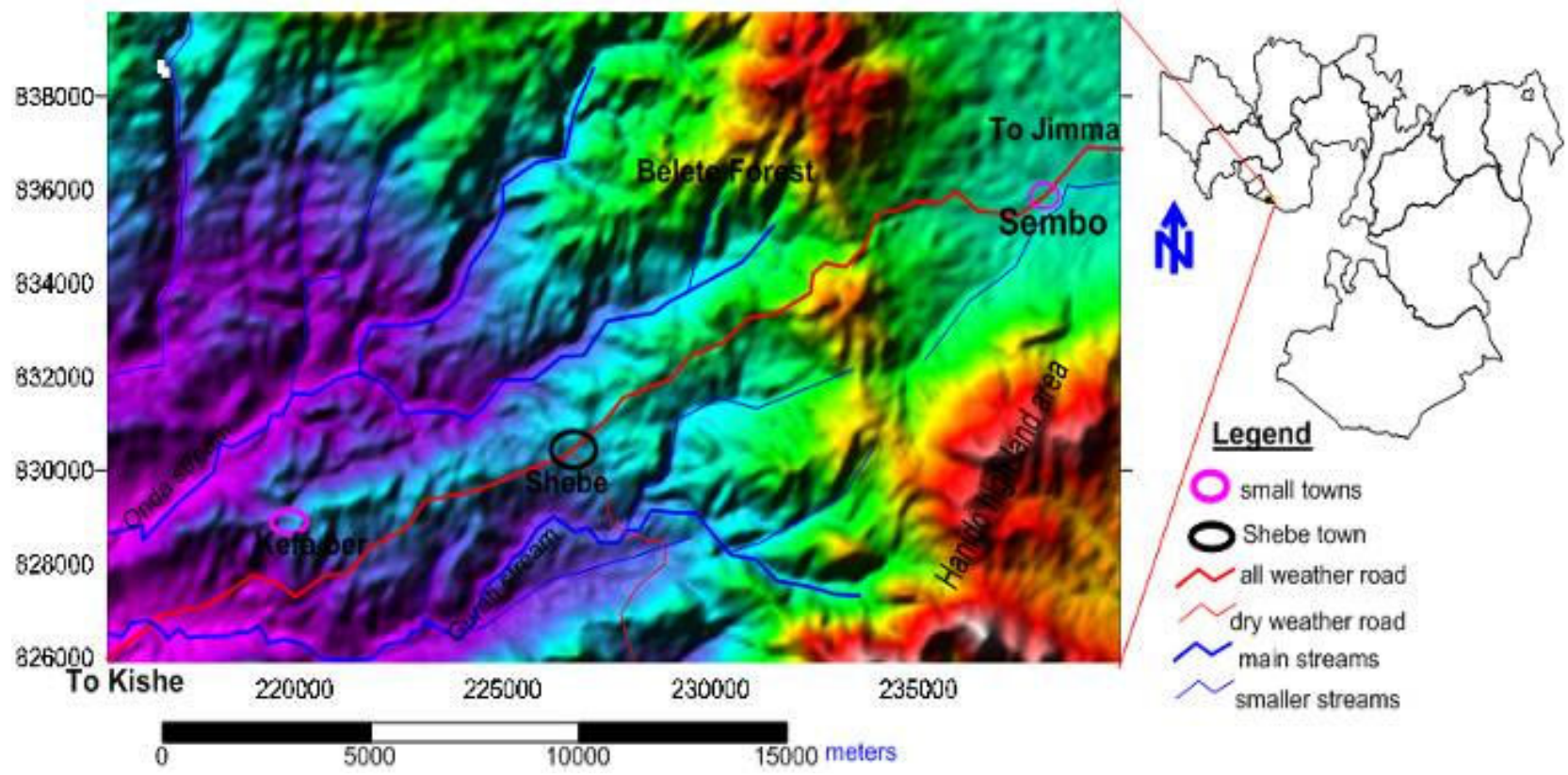

Figure 1: Accessibility, drainage and location map of Shebe area.

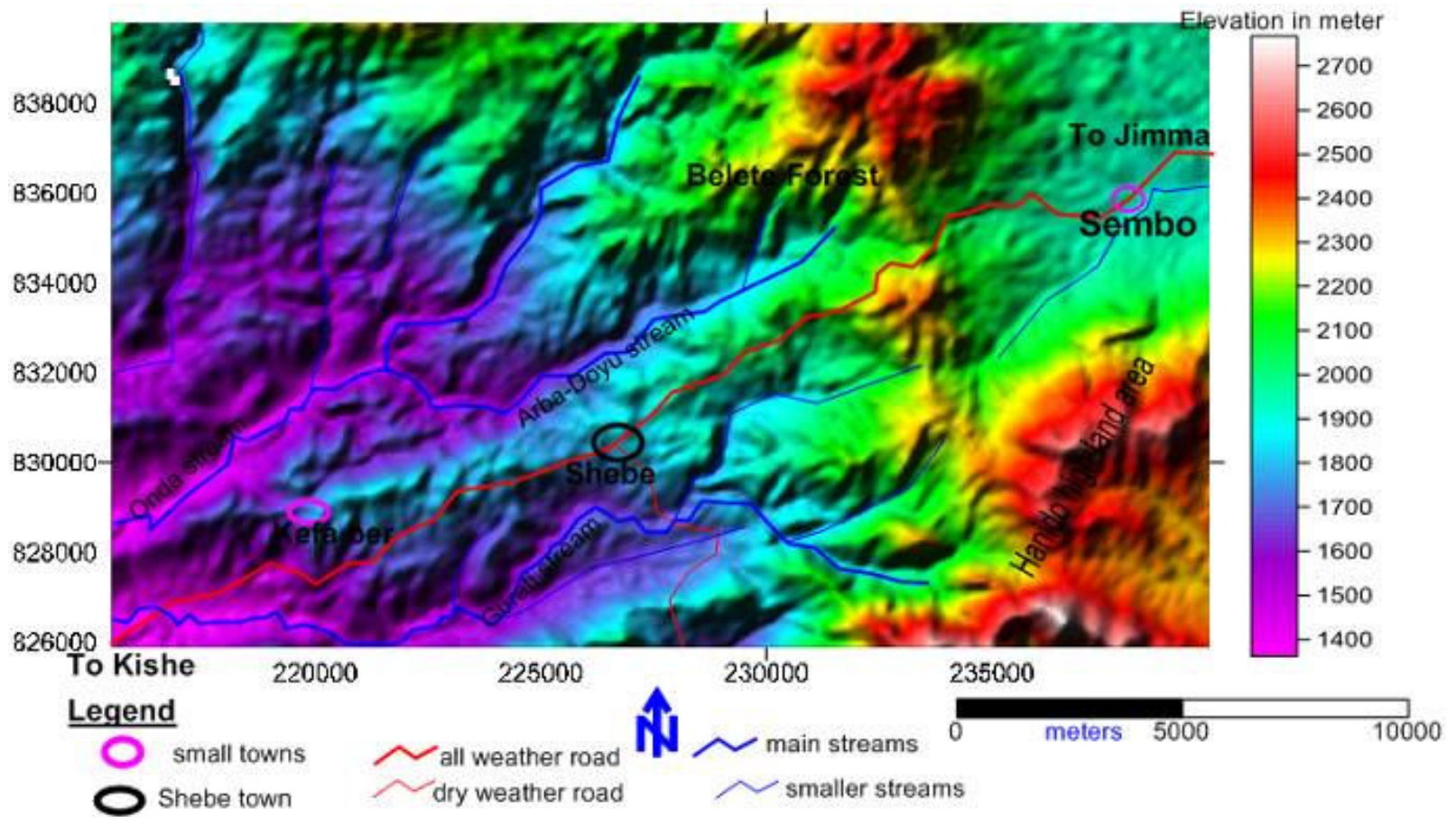

Figure 2: Physiographic and drainage system of Shebe area. 


\section{Geremew Lamessa}

The physiographic land feature of the study area is formed by the volcanic activities, erosion and deposition, and the underlying geology with some local structural influence. The area is characterized by mountains, highly rugged and dissected topography with deep slopes and the lowest parts of the area is characterized by valley floor with flat to gentle slopes. The elevation of the area ranges from $1350 \mathrm{~m}$ to $2750 \mathrm{~m}$ a.s.l.

According to the annual rain fall mapping (Ethiopian Meteorological Agency, 1976) the study area gets annual rain fall ranging from $2000 \mathrm{~mm}$ to $2399 \mathrm{~mm}$. Moreover the area is characterized by elevation ranges from $1350 \mathrm{~m}$ to $2750 \mathrm{~m}$ amsl. This elevation range is intern characterized by average temperature of $16-20$ ${ }^{0} \mathrm{C}$.

It has been observed that in general the average annual temperature decreases with an increase in altitude. This basis, five traditional temperature or climatic zones are differentiated in a description presented by the Ethiopian Mapping Agency (1981) in the National Atlas of Ethiopia. Accordingly the study area is characterized by subtropical (Weina-Dega) climatic zone (1500$2300 \mathrm{~m}$ elevation and $15-20^{\circ} \mathrm{C}$ mean annual temperature).

The Present research work was conducted conduct Geological investigation, hydrogeophysical investigation and assess groundwater potential site of the Shebe watershed with following objectives.

- identification of the major water bearing formations;

- characterization of aquifer using resistivity distribution

- implementation of sustainable potable water supply through source identification

- Supply safe/ potable water for the town

- identification of recharge-discharge areas ;

- determining depth to the water bearing zone;

- mapping promising ground water zones in hard rocks,

- estimating ground water salinity (problems connected with quality) etc.

- To recommend an alternative water source

\section{MATERIALS AND METHODS}

The methods used in this study include literature review, field investigation, and data analysis using different software. Aerial photographs and topographic maps at a scale of $1: 50,000)$ were studied carefully. The aerial photographs were used to identify the geological structures and trace them on to the topographic
STAR Journal, July-Sep 2012, 1(3): 45-58

sheet of 1:50,000 scale. The topographic sheet was used as base map in the field to mark the lithologies, their contacts and trends and to develop detailed geological and hydrogeological maps of the area.

Primary geological and hydrogeolgical data were collected in the field after having the secondary data. Hydrogeological field investigation was concentrated more on differentiating the rock units of groundwater significance (such as the degree of fracturing of the rock units, the extent of weathering, the type and degree of cementation, the thickness of the formations, the grain size, shape and sorting, and the clay proportion) and in collecting hydrogeological information, i.e., locating of water points, and measurement of discharge of wells. The occurrence of groundwater depends not only on the nature of the rock but also in their geologic history.

Aquifers in the area of investigation were classified based on two factors: qualitative and quantitative classifications (Bayissa Asfaw, 2003). In areas where hydrogeological data are not available field observations such as distribution and magnitude of discharge of spring, degree of fracturing of rocks, grain size, rounding and sorting type and degree of cementation, depth and extent of weathering were taken in to consideration.

Data of pumping test such as yield and drawdown were used for classification by calculating transmissivity and hydraulic conductivity of the area. Based on these data together with topographic setting, and recharge conditions were used to classify aquifers according to productivity.

With the framework of the preliminary geological, hydro geological and hydrological models, the geophysical survey was conducted with the objective of defining the most favorable location for borehole in shebe town. Thus, the survey was required to prove more data on the presence and thickness of the aquifer system, the depth to the impermeable layer, to estimate the depth of the water level and to estimate the total depth of drilling. Therefore three Vertical Electrical Soundings were performed at specifically pinpointed sites based on the accessibility for lay out of the instrument and respective cables.

\section{Survey Specification and Instruments}

The instrument used in this study work is latest instrument SAS 400 model with electrode spacing 
Geremew Lamessa

of $A B / 2=>750 m$ which is the standard. The number of soundings done is three because two deep wells are required for the town. The said instrument is rugged, portable, and used friendly and has been put in use in many sites investigation. Measurement was taken at increasing current electrodes distance such that in principle, the

$J=\frac{I}{A}=\frac{\mathrm{I}}{2 \pi \mathrm{r}^{2}}$

By Ohm's law $\mathrm{E}=\rho \boldsymbol{J} \Rightarrow \boldsymbol{E}=\frac{\rho I}{2 \pi r^{2}}$
STAR Journal, July-Sep 2012, 1(3): 45-58

injected electric current should be penetrating at greater depths. Now, consider a single electrode, placed on an electrically homogeneous and isotropic half space of resistivity, $\rho$. The current density at distance $r$ :

For current strength, I in a hemispherical ground section of resistivity $(\rho)$, the potential $V$ at distance $r$, from the electrode is given by: $\boldsymbol{V} \frac{\rho I}{2 \pi r}$, since

$V=E \cdot r$

Eqn. 3

Four-Electrode configuration Layout (Figure 3), C1(A) and C2(B) are current electrodes, while $\mathrm{P} 1(\mathrm{M})$ and $\mathrm{P} 2(\mathrm{~N})$ are potential probes.
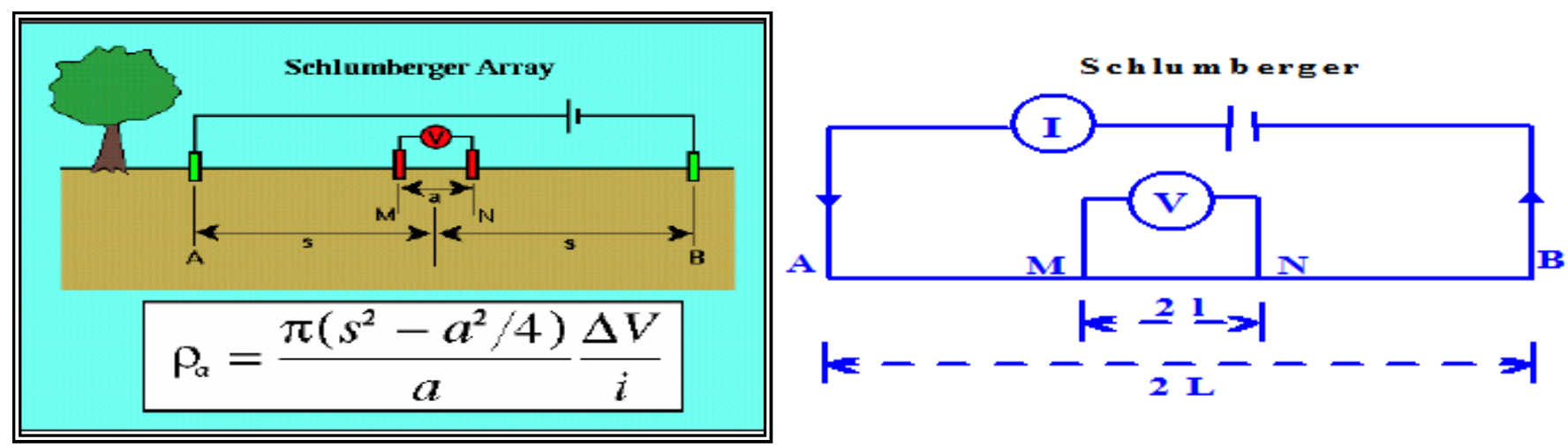

Figure 3: Four- Electrode Configuration layout.

The potential measured at P1 due to currents entering and exiting via $\mathrm{C} 1$ and $\mathrm{C} 2$, is:

$V_{p 1}={ }_{2 \pi}^{\rho I}\left\lfloor\frac{1}{r_{1}}-\frac{1}{r_{2}}\right\rfloor$ And, at $p_{2}$ is:- $V_{p 2}={ }_{2 \pi}^{\rho I}\left\lfloor\frac{1}{r_{3}}-\frac{1}{r_{4}}\right\rfloor$

Eqn. 4

In practice, a potential difference rather than a potential, is measure. Hence, the Potential difference between $\mathrm{P} 1$ and $\mathrm{P} 2$ is given by:

$\Delta V=V_{p 1}-V_{p 2}=\frac{I \rho}{2 \pi}\left[\frac{1}{r_{1}}-\frac{1}{r_{2}}-\frac{1}{r_{3}}+\frac{1}{r_{4}}\right]$

Eqn. 5

$\rho=\frac{\Delta V}{I}\left[\frac{\frac{1}{r_{1}}-\frac{1}{r_{2}}-\frac{1}{r_{3}}+\frac{1}{r_{4}}}{I}\right]=\frac{K \Delta V}{I}$

Eqn. 6

Where $\mathrm{K}$ is called the geometric factor and depends upon the positions of the electrodes in a specific array given by

$\mathbf{K}=\frac{2 \pi}{\frac{1}{r_{1}}-\frac{1}{r_{2}}-\frac{1}{r_{3}}+\frac{1}{r_{4}}}$

Eqn. 7 
A measured value of apparent resistivity at a point is not necessarily a representative of the true resistivity of any element in the earth neither is a simple average of true resistivity. It does, however, vary systematically across a geologic section and can be diagnostic of both layering and of the

The simplest method of carrying out a resistivity survey is to arrange the four electrodes in a straight line (collinear arrays) on the surface of the ground, i.e., two current electrodes (a positive one through which current enters the ground and a negative one to which it returns) and, the other two electrodes to measure the resulting potential difference. In this study I used SCHLUMBERGER arrays. The apparent resistivity values are plotted against the half current spacing $A B$ using log-log sheet. These plots represent the field curves, which were immediately interpreted qualitatively in the field and later subjected to computer assisted iterative interpretation based on IPI2 WIN Package. I attempted to interpret the resulting set of layer parameters of resistivity distribution in terms of their litho logic equivalent in relation to local geological formation and existing water source of the town.

\section{Electrode Configuration}

Vertical Electrical Sounding (VES) were carried out by using the symmetrical Schulumberger expanding spread. In the method, the resistivity measurements were taken by progressively presence of conductive or resistive in homogeneities. We thus, write the expression for the apparent resistivity as:

increasing the Potential Electrode (MN) along with a relatively large increment of the Current Electrode $(A B / 2)$. The Potential Electrode $(M N)$ separation ranges from $1 \mathrm{~m}$ to $90 \mathrm{~m}$ whereas; the Current Electrode Separation (AB/2) of $750 \mathrm{~m}$ was stretched to achieve maximum depth of penetration.

\section{Location of VES}

The geophysical investigation conducted in the area is Electrical Resistivity Sounding (VES). The VES was conducted in the Southwestern- North Eastern direction for VES1 at GPs Location of 37P, $222290 \mathrm{mE}$, UTM, $827975 \mathrm{mN}$ and elevation $1679 m$.a.s.l. North -south direction for VES2 at GPs Location of 37P, 222434mE, UTM, $828025 \mathrm{mN}$ and elevation $1882 \mathrm{~m}$.a.s.l. both at the site of Bake Qobo for comparison and recommending best site. The other VEs has been conducted on the other side of catchment at North western from Shabe town at the Shabe Daso site at a specific location of 37P, 224115mE, UTM, $831201 \mathrm{mN}$ and elevation $1554 \mathrm{~m}$.a.s.l. as it is displayed on Figure 4 for the location of Vertical Electrical soundings for the town.

\section{From Pos: 37.22229000, 8.27975000To Pos: 37.22411500, 8.31201000}

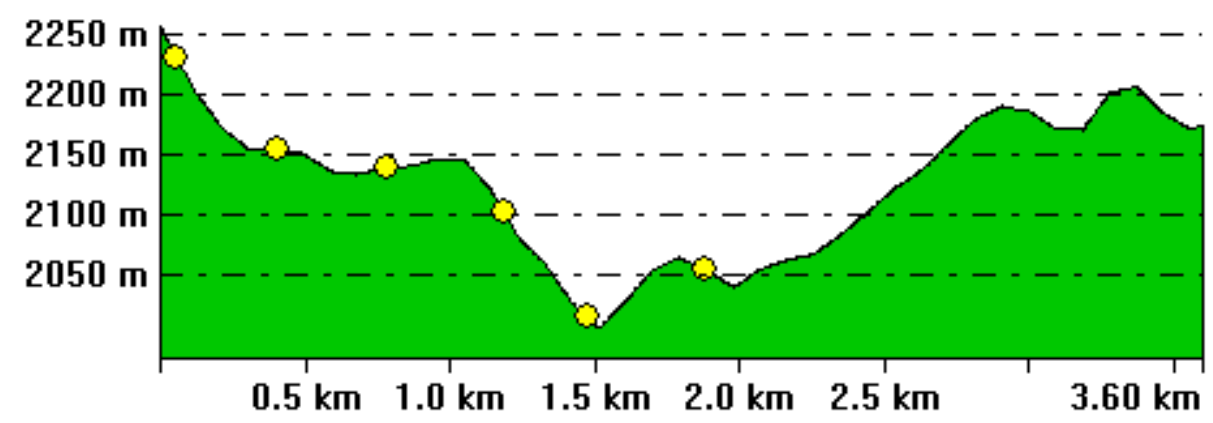

Figure 4: Location of Vertical Electrical Soundings for Shebe town.

\section{Data Analysis and Interpretation}

Different software such as Arc GIS, surfer, GWW, IPI2win, Global Mapper and Microsoft Excel are used to develop maps and cross-sections, and analyze the data. The analyzed data is then interpreted scientifically to meet the specified aims.Generally, Personal observation, history telling, technical measurements, Geophysical survey guided walk, and other techniques were applied to collect primary data. Even though, we try to collect secondary data we could not get it. Finally, the collected data were organized, analyzed. 


\section{RESULTS AND DISCUSSION}

\section{Geology}

The main rock unit around the study area consists of one main lithologic rock groups, tertiary volcanic rocks (Jimma volcanics).

\section{Jimma Volcanics (Pjb and Pjr)}

Jimma volcanic comprises trachyte basalts and rhyolites which covers most part of the southwestern Ethiopia. It forms a thick succession of basalts and felsic rocks with basalts dominating the lower part of most section. It has two parts Jimma basalt (Pjb) and Jimma rhyolite (Pjr) which shows a conformable relationship was identified. Jimma rhyolite is the younger one. The jimma volcanic almost always rest on the Precambrian basement, the unconformity being marked by basal residual sandstone. The basalt flows form an unbroken succession several hundred meters thick in some places. On others felsic rocks are interbeded with basalt flow close to the base or form a thick succession just above the basal basalts (Geological survey of Ethiopia, 1988).

\section{Local Geology of the study areas}

In the study area tertiary volcanic rocks and resent deposits are observed during intensive field work as it can be seen for Geological map of Shebe Area Figure 5. The volcanic rocks include basalt, Trachyte at south and west of Shebe town (quarry site) (Figure 6), Ignimbrite and fall/surge deposits (Figure 7). The recent deposits include alluvial deposits.

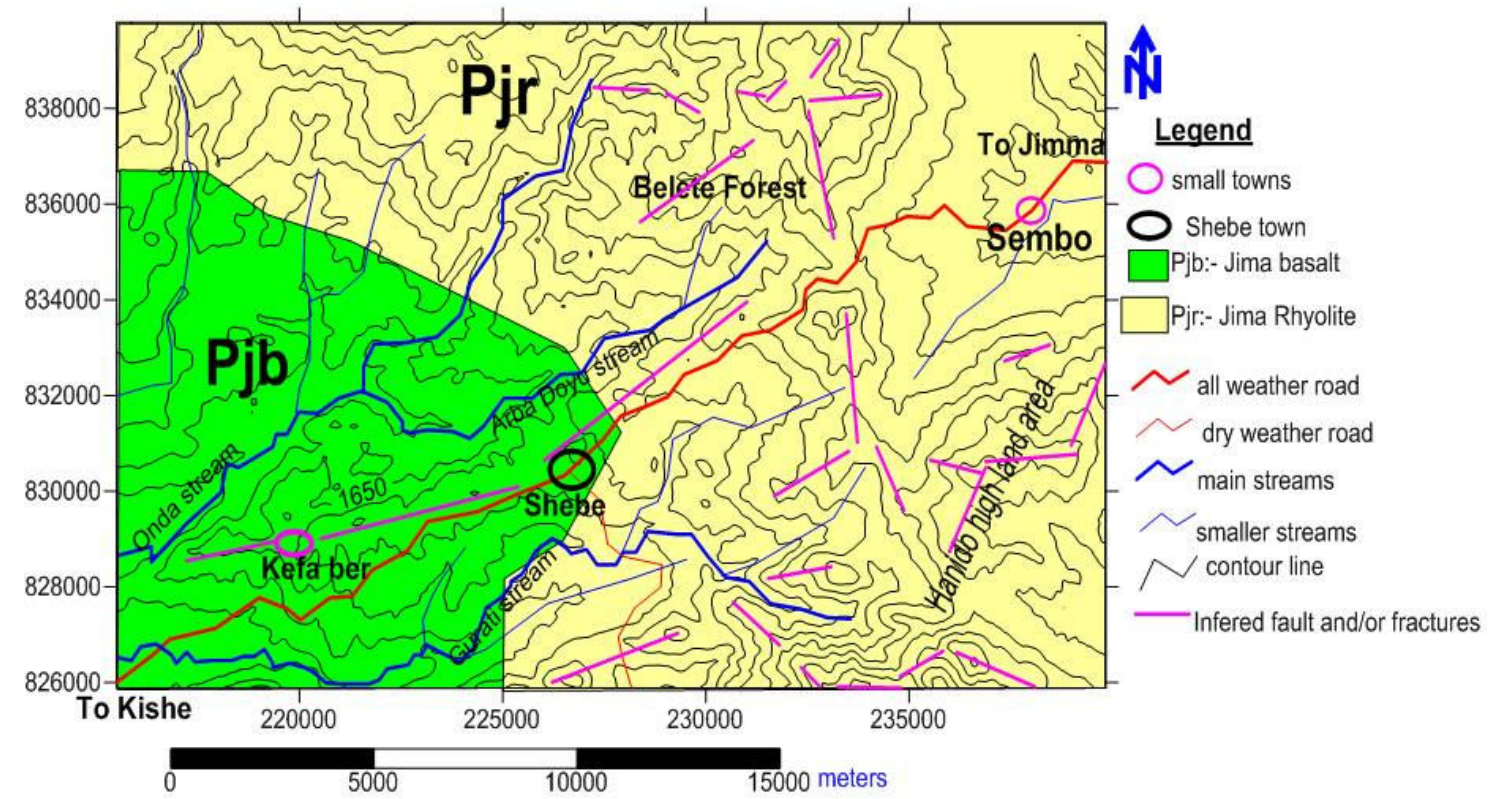

Figure 5: Geological map of Shebe area, (modified from geologic map of Ethiopia, 1988).

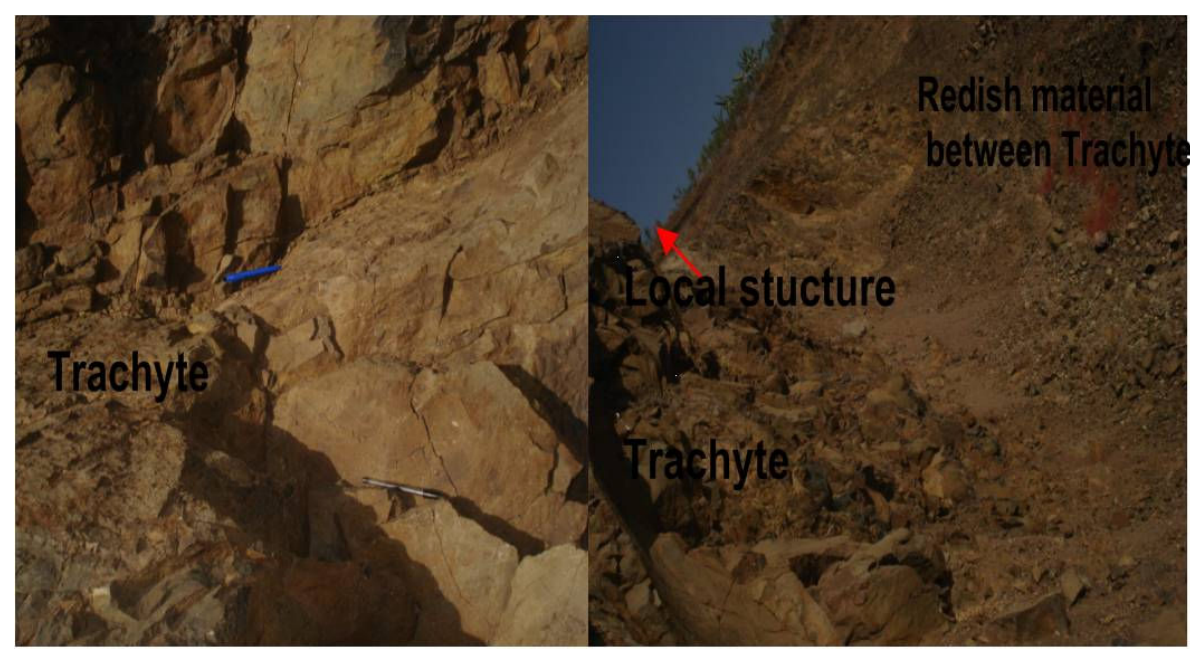

Figure 6: Trachyte at south and west of Shebe town (quarry site). 


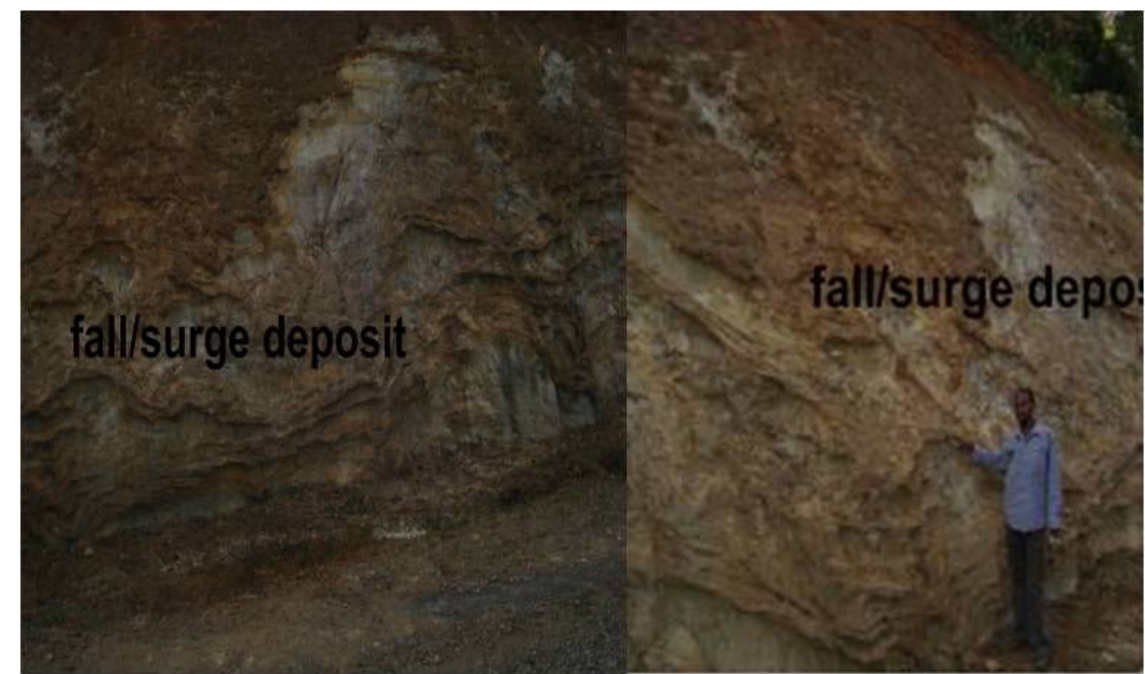

Figure 7: Fall/Surge deposit at North of Shebe town (road cut).

\section{Tertiary Volcanic Rocks}

This rock unit is out-cropped to west the Shebe town at Arba-Doyu stream Figure 8. It covers some part of the stream bed, but not exposed on sloppy area. The rock is highly weathered and fractured as observed at its outcrops due to stream cuts. This unit has thickens of 1 meter at its outcrop. It is overlain by trachyte at one place and by alluvial deposit at another place. The seepage springs are observed at the contact of basalt and alluvial deposit. This unit may correlate with the Jimma basalt of regional geology. Trachyte is observed to the southern and western part of Shebe town on the sloppy part due to road cut \& quarry for road construction and stream cut (Figure 6). At its western part it overlays' directly on the basalt and covered by thin clay soil, due to it's highly weatheredness at its top part grasses are growing on it and it is almost changed to soil. It is also exposed on pedistrile sloppy road for almost 40 meter thick. At its southern outcrops (quarry and road cut), it is relatively fresh than the western part. It is highly fractured and somehow weathered at its top. At the quarry sit it exposed about 10 meter with 1 meter clay at its top. It is gray at its fresh part and reddish at its weathered part. It is affected with local structure. The Ignimbrite part is exposed to the west and south of Shebe town due to quarry and road cuts (Figure 9). At the quarry site (south of the town), it is exposed about 35 meter affected by local structure. It is highly weathered and fractured, even almost changed to soil to north of the local structure.

This deposit is found in the valley sides of both Gurati and Arba Doyu stream sides. Even though, it is not mapped on regional geologic map it covers wider parts of the Gurati valley. This unit has 4 meter at Gurati stream exposed due to bridge construction on the stream and 0.5 to 2 meter dark, gray and reddish soil is exposed on sloppy area due to erosion. The soil on valley part has different colors depending on its source and forms stratified system.;- black and gray having boulder size rocks in it at stream cut sides.

\section{Geological Structure}

The major structures around study areas are mainly localized in the high land areas mainly having a series of NE-SW and N-S normal faults (Figure 10). In addition to the above structures a nearly E-Wand NW-SE lineaments are observed around the northern and south east study area. These structural elements within the study area are identified by the combination of the results from Land sat imagery and Digital Elevation Model (DEM) analysis and field observation. The tectonic structures are associated with the extensional tectonics. These include faults, folds, fractures, and joints having different magnitude and orientation.

\section{Hydrogeology}

There are three important geological patterns that control the nature \& distribution of hydrogeological units in geologic system. These are litho-logy, strati-graphy \& structures of the geologic formation. Litho-logy is the physical make-up of the sediments (rock) that make up the geologic system, example mineral composition, grain size \& grain packing. Stratigraphy describes the geometrical and age relationships between various formations in geologic system. Structural features, such as fractures and faults are the geometrical 


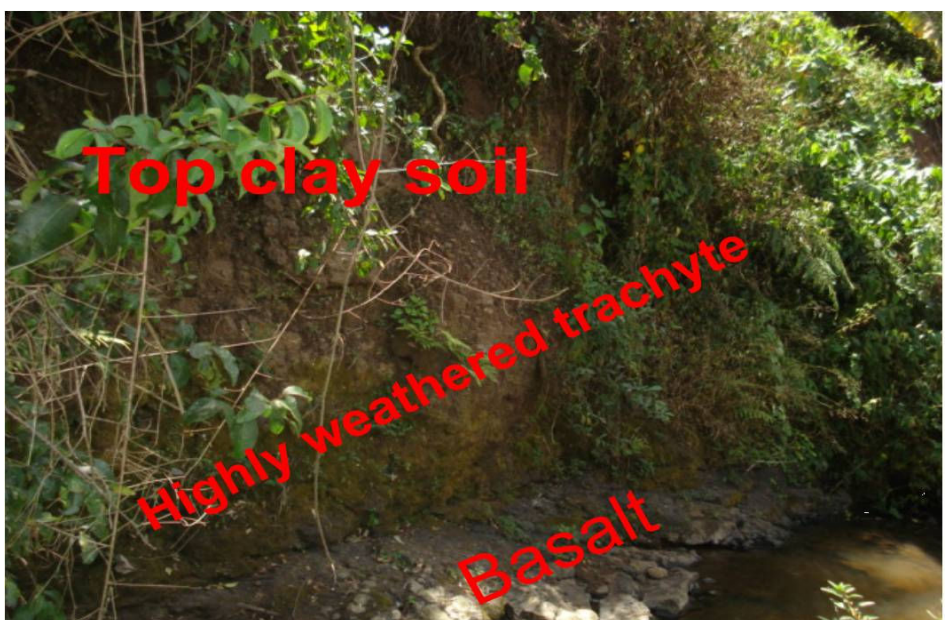

Figure 8: Top clay soil highly weathered trachite and basalt (Arba-Doyu stream).

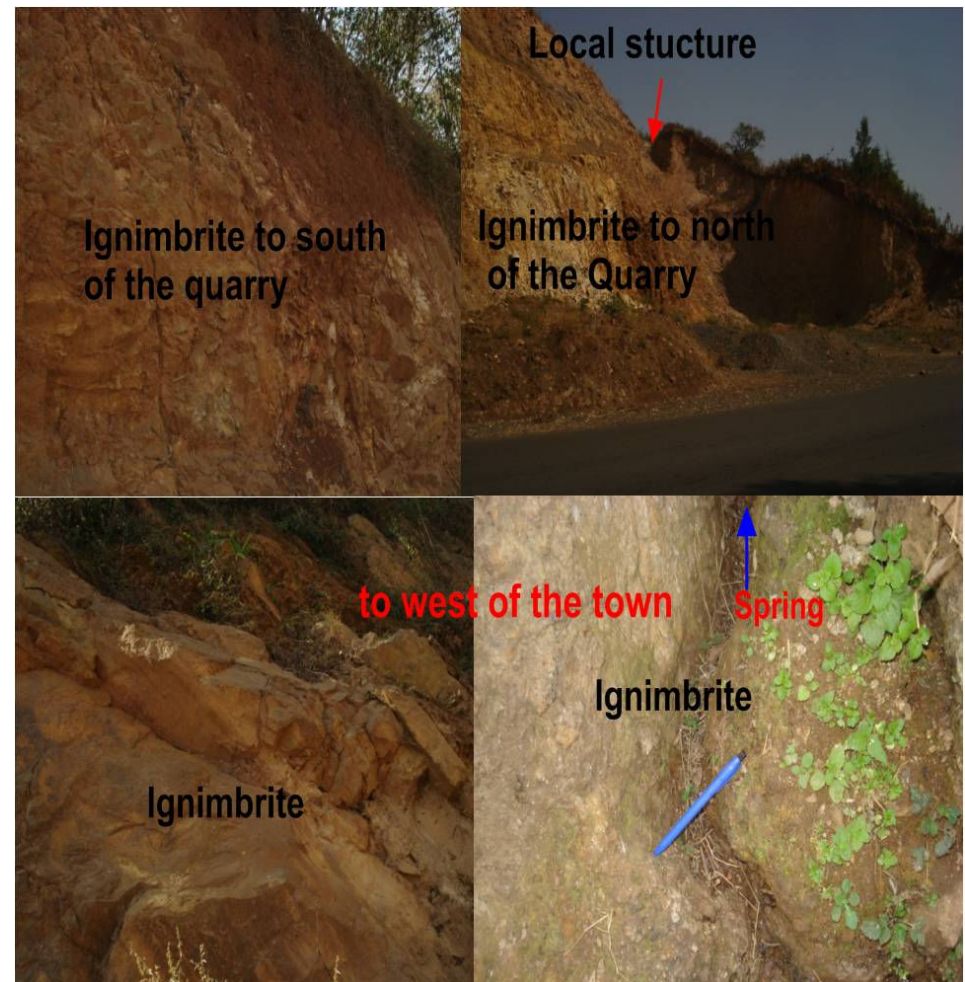

Figure 9: Ignimbrite at south west of Shebe town where there is spring.

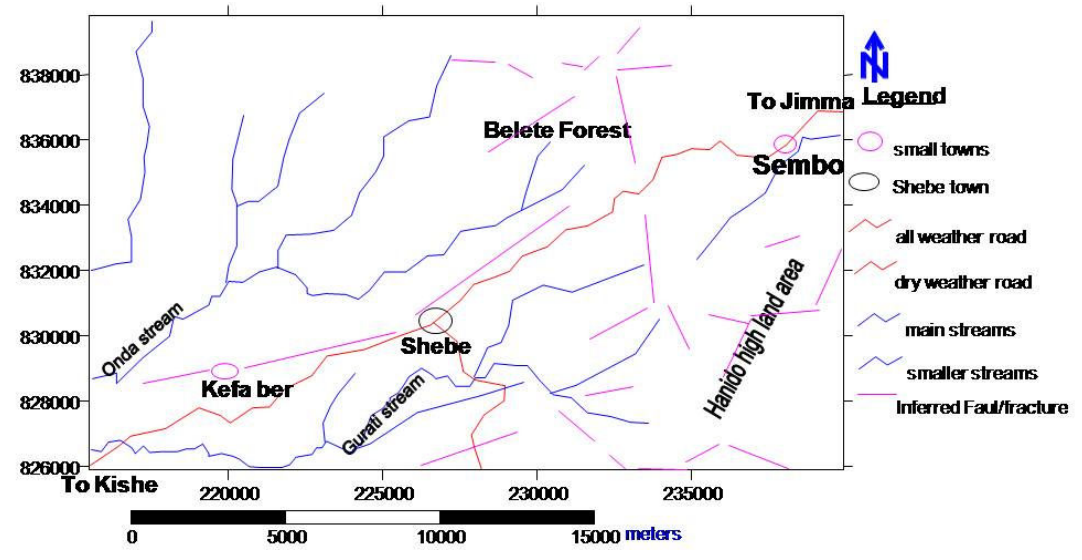

Figure 10: Structural map of shebe area. 


\section{Geremew Lamessa}

properties of geologic system produced by tectonism or during crystallization.

Volcanic rocks are aquifers due to their primary and/or secondary porosity (fractures, etc), from where springs \& some streams in this lithology are starting and flow following fracture line.

Ground water is present in almost all landscapes. The interaction of Ground Water with surface water depends on the physiographic and climatic setting of the landscape. Some rocks,
STAR Journal, July-Sep 2012, 1(3): 45-58

found in mountain terrain, underlying soil may be highly weathered and fractured and may transmit significant additional amount of water flow through the subsurface.

According to Tesfaye (1985) reports lithologic units found in our study areas are categorized under three hydrogeological types (Figure 11). These are Sediments with dominant intergranular permeability (Aquifer with moderate to high productivity) and Volcanic rocks-variable fracture and fissure permeability (Aquifers with moderate productivity).

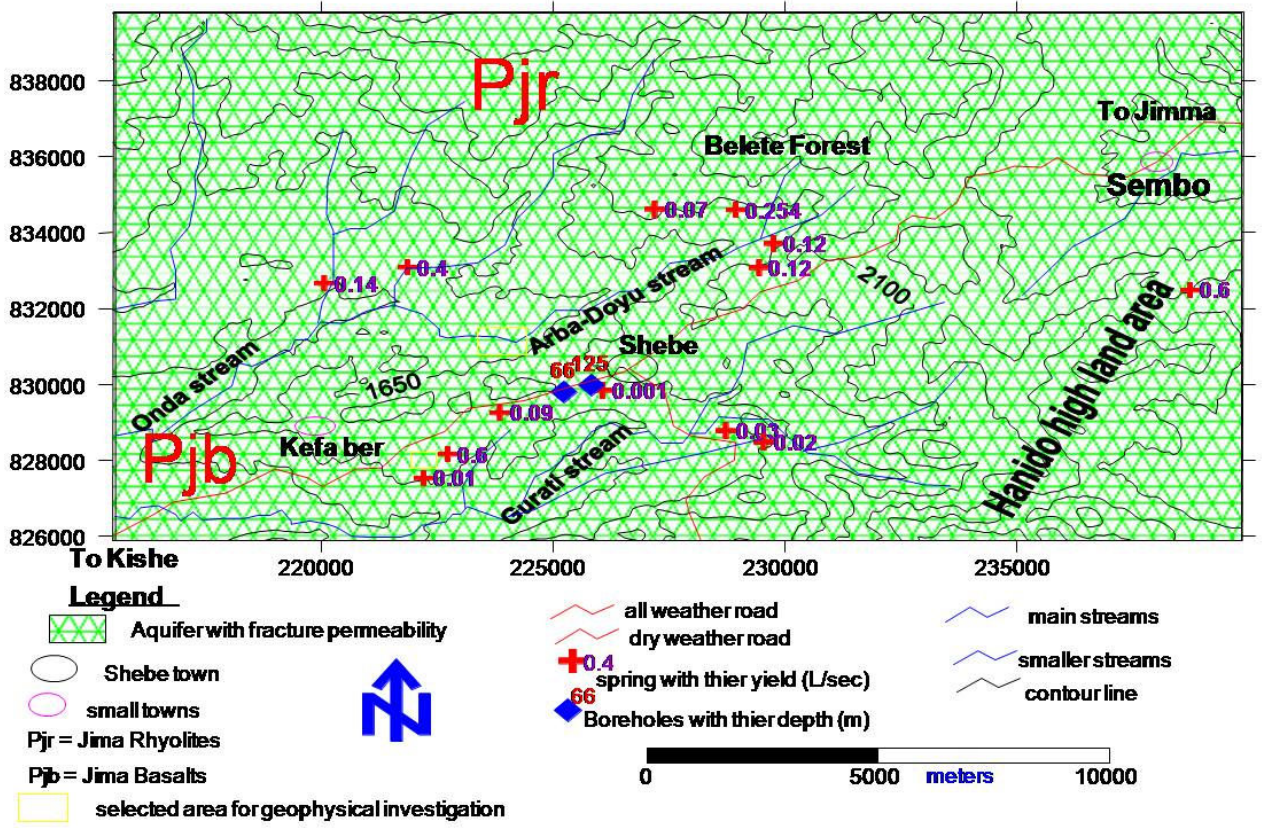

Figure 11: Hydrogeological map of Shebe area, modified from geological map.

\section{Geo Electric Models}

\section{VES 1}

The plotted field data below shows a five layer curve (Figure 12, Figure 13, and Figure 14) for Resistivity inversion model for VES1,VES2 and VES3 respectively. Interpretations were performed similar to the above studies by an inversion approach that requires a best an initial guess for a starting model and then refines that model by iteratively reducing the error between forward calculations from the current state of the model and the field data. The iterative process is stopped when the error meets acceptable range.

The result for the first VES1 gave six layers model of resistivity $\rho 1<\rho 2>\rho 3<\rho 4>\rho 5<\rho 6$

\section{VES2}

The result for the second VES2 gave a six layer model of resistivity $\rho 1<\rho 2>\rho 3<\rho 4>\rho 5<\rho 6$

\section{VES3}

The result for the third VES3 gave a six layer model of resistivity $\rho 1>\rho 2<\rho 3<\rho 4<\rho 5<\rho 6$

\section{Geo Electric Sections}

The results of the geophysical survey is based on vertical electrical sounding (VES) of the electrical resistivity method are a function of apparent resistivity ( $\rho a)$ and current electrode separation. Computer iteration techniques was employed by using software IPI2 WIN for the interpretation of apparent resistivity data that produced the computer iterated sounding curves shown in Figures 6,7 and 8 and lithological Tables 1 that show the various lithologic units level. 


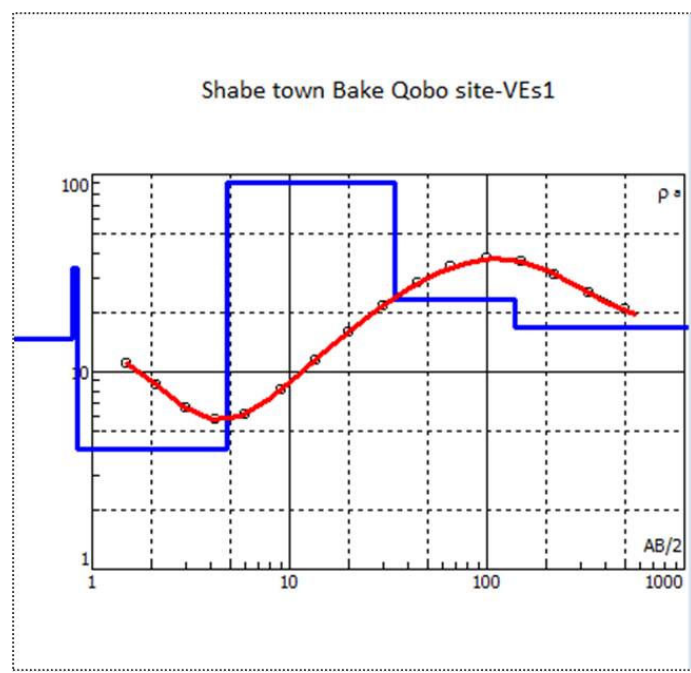

\begin{tabular}{|c|c|c|c|}
\hline \multicolumn{3}{|c|}{ I7 $\mathrm{RMS}=0.211 \%$} & 口 ⿷匚 \\
\hline $\mathbf{N}$ & $\rho$ & h & d \\
\hline 1 & 14.7 & 0.793 & 0.793 \\
\hline 2 & 33.2 & 0.0505 & 0.844 \\
\hline 3 & 4.03 & 3.99 & 4.83 \\
\hline 4 & 91.6 & 29.3 & 34.1 \\
\hline 5 & 23.3 & 104 & 138 \\
\hline 6 & 16.8 & & \\
\hline
\end{tabular}

Figure 12: Shebe town Bake Qobo site Resistivity inversion model -VES 1.

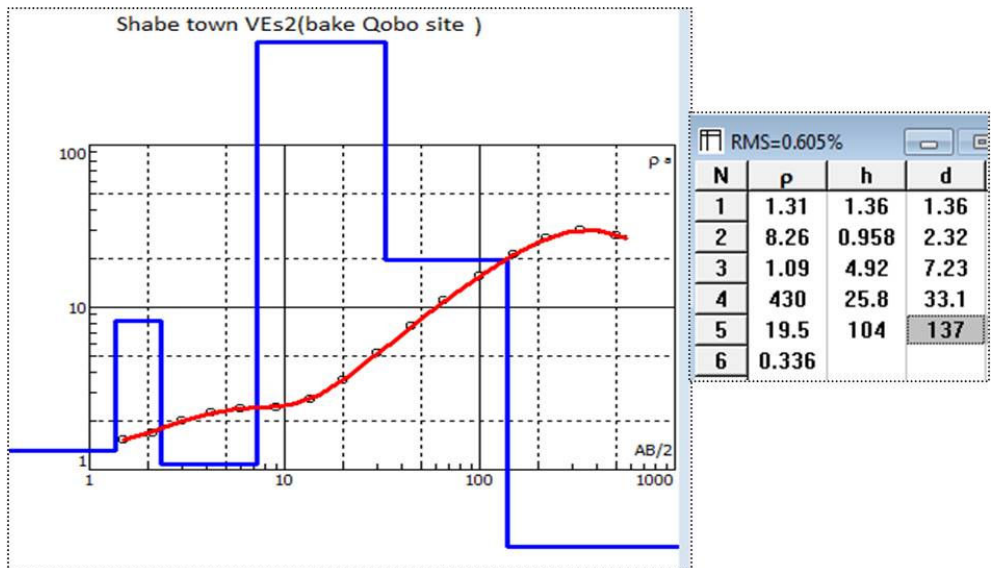

Figure 13: Shebe town Bake Qobo site -Resistivity inversion model -VES 2.

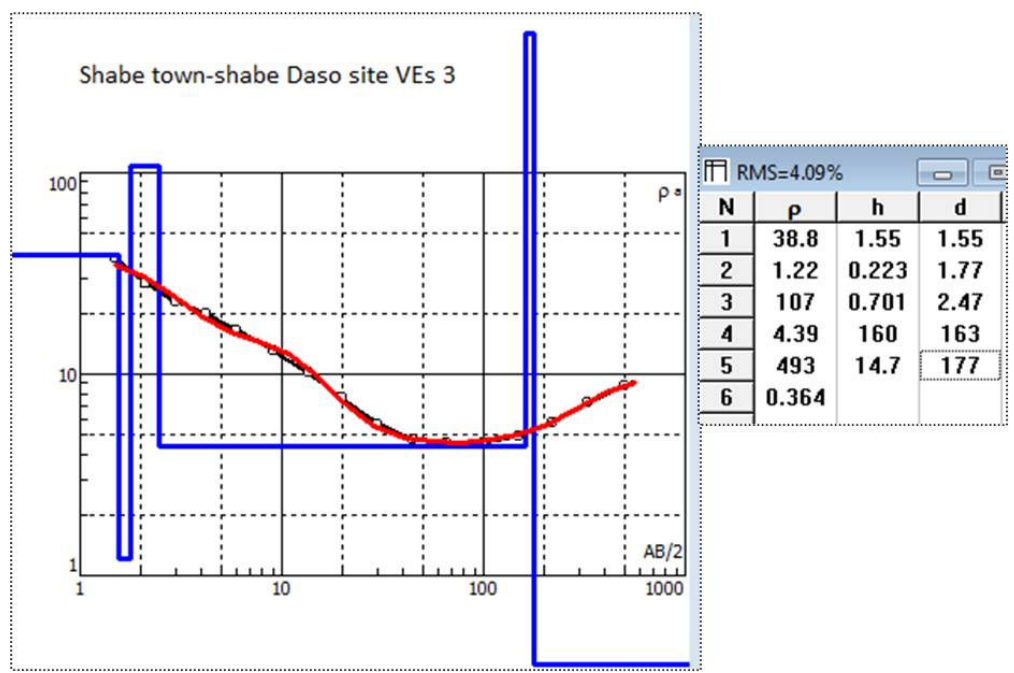

Figure 14: Shebe Town Shabe Daso site-Resistivity inversion model-VEs 3. 
Table 1: Location and yield of some springs in the study area.

\begin{tabular}{cccccccc}
\hline Easting & Northing & Elevation & Source & Code & Name & $\begin{array}{c}\text { Estimated } \\
\text { Q(I/sec) }\end{array}$ & Status \\
\hline 226056 & 829848 & 1727 & Spring & S1 & Danga & 0.001 & Undeveloped \\
227181 & 834620 & 1815 & Spring & S10 & Sebaka & 0.07 & und \\
223845 & 829261 & 1941 & Spring & S11 & Yadi & 0.09 & undeveloped \\
222717 & 828161 & 1677 & Spring & S12 & Berro & 0.6 & undeveloped \\
222195 & 827539 & 1653 & Spring & S13 & Adminstration & 0.01 & undeveloped \\
228720 & 828791 & 1740 & Spring & S2 & Melka Omo & 0.03 & - \\
229538 & 828489 & 1771 & Spring & S3 & Giddi & 0.02 & - \\
229431 & 833087 & 1987 & Spring & S4 & Chaffe 1 & 0.12 & undeveloped \\
229743 & 833723 & 1913 & Spring & S5 & Chaffe 2 & 0.12 & undeveloped \\
228926 & 834601 & 1873 & Spring & S6 & Sombo & 0.254 & undeveloped \\
221848 & 833091 & 2020 & Spring & S7 & Qartame & 0.4 & undeveloped \\
220058 & 832673 & 2023 & Spring & S8 & School & 0.14 & undeveloped \\
238731 & 832500 & 1948 & Spring & S9 & Jimal & 0.6 & undeveloped \\
\hline
\end{tabular}

By integrating the resistivity results with the borehole/drillers log litho logy/geology, resistivity interpretation for the VES stations 1, 2 and 3 were obtained.

The VES 1 and VEs 2 at the Bake Qobo Site almost reflect the same results, as it is reflected in the fifth geo layer $\rho 5$. This layer with depth of around $140 \mathrm{~m}$ represents relatively fractured bed rock/interlava flow gaps of different episodes filled by mixed gravels, sand, silt and clay or equivalently can be interpreted as the most upper part of highly weathered and disintegrated basement rock and fractured bed rock in which the discontinuities are filled with water. And in case of VES 3 the fourth geo layer $\rho 4=4.39 \Omega \mathrm{m}$ represents relatively fractured bed rock/interlava flow gaps of different episodes filled by mixed gravels, sand, silt and clay and the fifth layer $\rho 5=493 \Omega \mathrm{m}$ can be the water bearing zones with depth must not be less than $170 \mathrm{~m}$.

The summary of lithology of the three soundings; VES1, VES2 and VEs 3 are represented in the Tables 2, 3 and 4.

Table 2: Summarized Lithology for VES- 1.

\begin{tabular}{ccccc}
\hline Layer & $\begin{array}{c}\text { Resistivity } \\
(\mathbf{o} \mathbf{m}-\mathbf{m})\end{array}$ & $\begin{array}{c}\text { Thickness } \\
(\mathbf{m})\end{array}$ & $\begin{array}{c}\text { Depth } \\
(\mathbf{m})\end{array}$ & \multicolumn{1}{c}{ Remark } \\
\hline 1 & 14.7 & 0.8 & 0.8 & \multicolumn{1}{c}{ Thin wet top soil } \\
\hline 2 & 33.2 & 0.05 & 0.8 & $\begin{array}{l}\text { Fresh bed rock of basalt and trachite rocks which } \\
\text { are not so affected by fractures and joints }\end{array}$ \\
\hline 3 & 4.03 & 4 & 4.8 & $\begin{array}{l}\text { Weathered materials resulted from the in situ } \\
\text { weathering of the basalt and trachite rocks } \\
\text { interpreted as zone of colluvial accumulates }\end{array}$ \\
\hline 4 & 91.6 & 29.3 & 34.1 & $\begin{array}{l}\text { Relatively not fractured bed rocks of trachite } \\
\text { Bed rock which is so affected by fractures and } \\
\text { joints which might be in this case basement rocks } \\
\text { of considered to be the aquifer bearing zone }\end{array}$ \\
\hline 6 & 104 & 138 & $\begin{array}{l}\text { The most upper part of highly weathered and } \\
\text { disintegrated trachitic rocks and fractured bed } \\
\text { rock in which the discontinuities are filled with } \\
\text { water }\end{array}$ \\
\hline
\end{tabular}


Table 3: Summarized Lithology for VES -2.

\begin{tabular}{ccccl}
\hline Layer & $\begin{array}{c}\text { Resistivity } \\
(\mathbf{o} \mathbf{m}-\mathbf{m})\end{array}$ & $\begin{array}{c}\text { Thickness } \\
(\mathbf{m})\end{array}$ & $\begin{array}{c}\text { Depth } \\
(\mathbf{m})\end{array}$ & \multicolumn{1}{c}{ Inferred Lithology } \\
\hline 1 & 1.31 & 1.36 & 1.36 & Thin wet top soil \\
\hline 2 & 8.26 & 0.96 & 2.32 & $\begin{array}{l}\text { Fresh bed rock of basalt and trachite rocks which } \\
\text { are not so affected by fractures and joints }\end{array}$ \\
\hline 4 & 1.09 & 4.92 & 7.23 & $\begin{array}{l}\text { The upper part of weathered materials resulted } \\
\text { from the in situ weathering of the basalt and } \\
\text { trachite rocks interpreted as zone of colluvial } \\
\text { accumulates }\end{array}$ \\
\hline 5 & 430 & 25.8 & 33.1 & $\begin{array}{l}\text { Layer not fractured bed rocks of trachite \& is not so } \\
\text { affected by fractures and joints }\end{array}$ \\
\hline 6 & 19.5 & 104 & 137 & $\begin{array}{l}\text { Bed rock which is so affected by fractures and } \\
\text { joints which might be in this case basalt and } \\
\text { trachitic rocks of considered to be the aquifer } \\
\text { bearing zone }\end{array}$ \\
\hline
\end{tabular}

Table 4: Summarized Lithology for VES-3.

\begin{tabular}{|c|c|c|c|c|c|}
\hline Layer & $\begin{array}{l}\text { Resistivity } \\
\text { (ohm-m) }\end{array}$ & $\begin{array}{c}\text { Thicknes } \\
(\mathbf{m})\end{array}$ & $\begin{array}{l}\text { Depth } \\
(\mathrm{m})\end{array}$ & Inferred Lithology & Remark \\
\hline 1 & 38.8 & 1.55 & 1.55 & Is thin dry top soil & \\
\hline 2 & 1.22 & 0.22 & 1.77 & $\begin{array}{l}\text { Weathered basalt and trachite rocks which are so } \\
\text { affected by fractures and joints. }\end{array}$ & \\
\hline 3 & 107 & 0.7 & 2.47 & Resistive layer not fractured bed rocks of trachite & \\
\hline 4 & 4.39 & 160 & 163 & $\begin{array}{l}\text { Fractured basalt rocks and could be good aquifer of } \\
\text { water bearing zone }\end{array}$ & \\
\hline 5 & 493 & 14.7 & 177 & $\begin{array}{l}\text { The most resistive layer and trachitic rocks overlain } \\
\text { and underlain by less resistive layers }\end{array}$ & \\
\hline 6 & 0.4 & infinity & infinity & $\begin{array}{l}\text { Bed rock which is so affected by fractures and joints } \\
\text { which might be in this case basalt and trachitic rocks \& } \\
\text { considered to be the aquifer bearing zone. }\end{array}$ & \\
\hline
\end{tabular}

\section{Water Resource}

Boreholes, Hand dug wells springs and streams are considered as water resources in the study area. They have been used for different social and economical purposes of the community with in the area. The availability of these water resources varies from place to place due to geomorphic set up of the area.

Boreholes are drilled wells with drilling machines (rigs) at different depth for different purposes. They are used for water supply, industries, irrigations, ground water monitoring and as injection wells for industrial waste disposal purpose. 2-Boreholes in the study are drilled mainly for water supply purposes. Both of them are drilled very close to the town. According to the information from user community and wereda officers, both are productive now, but one has low yield (66meter depth) and the other (125meter depth, giving $7.5 \mathrm{l} / \mathrm{sec}$ yield) has water quality problem. Both Boreholes have no any hydrogeological data except the depth and estimated discharge of one well $7.5 \mathrm{l} / \mathrm{sec}$. both are located very close to each other.

These are very shallow ground water sources. They are excavated in the top alluvial deposits and some parts of the underlying weathered rocks. Hand dug wells are good sources of water where local or regional ground water is very shallow.

In the study area, local peoples use manually dug wells from alluvial silty clay soils. Most hand dugs are found in southwest part of the town and are old constructed and hand pump is installed on one of them. The maximum drilling hand dug well in the study area is 10 meter.

Natural springs may be defined as points, lines, or limited area of earth's surface through which ground water rises up according to hydro- 
geological characteristics of various water bearing formations occurring at shallow or greater depth. Springs occur in many forms and have been classified by means of their origin, rock structure, discharge, temperature and variability (Tenalem Ayenew and Tamiru Alemayehu, 2001). Spring is a way in which a concentrated discharge of ground water appears at the ground surface as flowing water forming a very small stream. Very small discharge is said to be seepage, but a relatively larger discharge could be defined as spring.

As explained by Foster et al. (1982), springs may form in two ways:

- A spring may formed where a fault has produced ground water barrier

- A spring may also formed if water accumulates over a localized aquiclud, example clay layer

In the study area, springs are the most common available and relatively evenly distributed water resource and location and yield of some springs in the study area are shown in (Table 3.1). Almost all springs in the area are formed due to local faulting and/or fracturing .They are emerging mainly at a foot of the slopes and on steep slope areas. Their discharge varies according to the recharge area coverage, fracturing effect, and seasonal variation. They display seasonal discharge variation. Some springs have an estimated discharge rate of 0.001-0. $6 \mathrm{~L} / \mathrm{sec}$.

Most streams are perennial and directly join the main streams in the form of surface runoff during dry seasons. Almost all streams in the study area are gaining type.

\section{Water Supply Options of the User Community Existing Water Supply}

The Shebe town community uses water from 2-borehole sources, unprotected springs, Hand dugs for drinking and other different activities, and nearby streams for cleaning and for their cattle without care for the water quality (pollution).

The community cannot get enough water from this water source, especially with respect to quality. Even though one borehole has $7.5 \mathrm{l} / \mathrm{sec}$ yield it has excess iron ion in its dissolved form.

\section{Proposed Water Supply}

From our field observation, there is no additional spring having better yield to develop it and the area is not promising for hand-dug well. The area may have good groundwater along the valley sides. So, two sites were selected and geophysical investigations were undertaken for deep wells at south and west of the town.

From Hydrogeophysical investigation,

- In both VES 1 and 2, the first geo media represents colluvial soil overburden the thickness of which varies from about $0 \mathrm{~m}$ to $1.4 \mathrm{~m}$ these layers collectively form the regolith which comprises alluvial deposits of fine to coarse grained sediments with varying hydraulic permeability.

- The fourth layer of VEs 1 \&2 comprise the succession of bed rock which is so affected by fractures and joints which might be in this case trachite rocks and is considered to be the aquifer bearing zone.

- But in the case of VEs 3 at the Shabe Daso site, it is the fifth geo layer $\rho 5=493 \Omega \mathrm{m}$ value that can be interpreted as the most resistive layer and trachitic rocks overlain and underlain by less resistive layers of thickness $14.7 \mathrm{~m}$ and could be the most water bearing zone.

\section{CONCLUSION}

The hydrogeological study reveals that the area consist of recent sediment deposits and volcanic rocks. Volcanic rocks area weathered and fractured which is suitable for groundwater abstraction through deep well drilling. Whereas recent sediment deposits may be suitable for shallow groundwater abstraction. Though the actual depth of a well is to be decided based on the actual situation during drilling, we conclude that from both VES 1 and 2 results, it can be safely be concluded that the target depth for well at Bake Qobo site of Shabe town should not be less than $140 \mathrm{~m}$. From the result of VES 3 at the Shabe site, because the fifth layer is confined between the two auriferous layers, the optimum depth for the water bearing zone must not be less than $170 \mathrm{~m}$. Since the springs found in the vicinity of the town have low yield, it is better to select the site for deep groundwater abstraction through deep well drilling. Based on the geological and hydrogeological conditions of the area, two areas are selected for further geophysical groundwater investigation. To see the extent of alluvial deposits and the nature of underlying volcanic rocks and their groundwater condition it is better to conduct geophysical survey at selected sites. The specific site for drilling, drilling depth and drilling method should 
be recommended after geophysical survey data analysis.

\section{ACKNOWLEDGMENT}

I would like to thank Boney a water consulting P.L.C for funding the study and my host work place Wollega University and also to Jima zone of water bureau and the workers of water office of Shebe Town.

\section{REERENCES}

Bayissa Asfaw (2003). Regional hydrogeological investigation of northern Ethiopia.

Encyclopedic Dictionary of Exploration Geophysics (1991). Third Edition, compiled by R. E. Sheriff, Society of Exploration Geophysicists.

Ethiopian Mapping Agency (1981). National atlas of Ethiopia, Addis-Abeba, Ethiopia, Pp 93

Geological map of Ethiopia, Nekemete sheet (2004)

Geological survey of Ethiopia (1988)

Interpretation Theory in Applied Geophysics (1976). Grant, F. S. and G. F. West, McGraw-Hill, 1965. Applied Geophysics, Telford, W. M., L. P. Geldart, R. E. Sheriff and D. A. Keys, Cambridge University Press.

Introduction to Geophysical Prospecting (1976). Third Edition, M. B. Dobrin, McGraw-Hill.

Kassahun. A (2008). Groundwater potential assessment of upper Dedessa river catchment. 